\title{
Diversity of the edaphic macrofauna in areas managed under no- tillage for different periods
}

\section{Diversidade da macrofauna edáfica em áreas de plantio direto com diferentes tempos de implantação}

\author{
Cláudia dos Reis Ferreira ${ }^{1 *}$; Jair do Nascimento Guedes²; Jean Sérgio Rosset ${ }^{3}$; \\ Lúcia Helena Cunha dos Anjos ${ }^{4}$; Marcos Gervasio Pereira ${ }^{4}$
}

\begin{abstract}
Agriculture can considerably change the composition and richness of the edaphic macrofauna, affecting the ecological and biological functions exerted by the fauna. This study was carried out in commercial production systems in the municipality of Guaíra, state of Paraná, Brazil. The objective of this study was to evaluate the effect of no-tillage systems (NTS) and seasonality on the diversity, richness, and composition of the edaphic macrofauna. Three areas managed under NTS for different periods 7 years (NTS-7), 14 years (NTS-14), and 23 years (NTS-23) under crop succession with soybean (summer) (aNTS7) and maize/wheat (winter) (NTS14 and NTS23) were evaluated, in addition to a native Atlantic Forest segment, which was used as a reference. Faunal samples were collected in the dry season (September 2013) and rainy season (February 2014). The edaphic macrofauna was evaluated using the method proposed by the Tropical Soil Biology and Fertility Program. Parametric statistics were applied, and the results were compared using Tukey's test at a level of significance of 5\%. Species density and total richness were usually higher in the NTS14 and NTS23 in the dry season. However, higher indexes of equability were not detected because of the dominance of groups Formicidae and Isoptera. The areas with the highest equability were the reference area in the dry season and NTS23 in the rainy season, corresponding to 0.87 and 0.61 , respectively. These results indicate the higher faunal diversity in these areas, which reflects the greater stability of the ecosystem.
\end{abstract}

Key words: Edaphic fauna. Biodiversity. Bioindicator.

\section{Resumo}

O uso agrícola pode alterar consideravelmente a composição e riqueza da fauna edáfica, influenciando nas funções ecológicas e biológicas desenvolvidas por estes organismos. O estudo foi realizado em sistemas agrícolas explorados comercialmente, no município de Guaíra - PR. O objetivo foi avaliar o efeito do tempo de implantação do SPD e da sazonalidade na diversidade, riqueza e composição da macrofauna edáfica. Foram avaliadas três áreas com diferentes tempos de adoção de plantio direto (PD), por 7, 14 e 23 anos, sob sucessão das culturas soja (verão) e milho/trigo (inverno) (PD7, PD14 e PD23

${ }^{1}$ Dra , Programa de Pós-Graduação em Ciência, Tecnologia e Inovação em Agropecuária, PPGCTIA, Universidade Federal Rural do Rio de Janeiro, UFRRJ, Seropédica, RJ, Brasil. E-mail: clreisferreira@gmail.com

2 Dr., Programa de Pós-Graduação em Agronomia, Ciência do Solo, CPGA/CS, Universidade Federal Rural do Rio de Janeiro, UFRRJ, Seropédica, RJ, Brasil. E-mail: jgrural@yahoo.com.br

3 Prof., Universidade Estadual de Mato Grosso do Sul, UEMS, Unidade Universitária de Mundo Novo, Mato Grosso do Sul, MS, Brasil. E-mail: rosett@uems.br

4 Profs., Departamento de Solos, Instituto de Agronomia, UFRRJ, Seropédica, RJ, Brasil. E-mail: mgervasiopereira01@gmail. com; lanjosrural@gmail.com

* Author for correspondence 
respectivamente), além de área de Floresta Atlântica como referência. As amostras de fauna foram coletadas nas épocas seca (setembro/2013) e chuvosa (fevereiro/2014). Para avaliação da macrofauna edáfica foi utilizado o método recomendado pelo Programa Tropical Soil Biology and Fertility. Foi aplicada estatística paramétrica e os resultados foram comparados pelo teste de Tukey, a $5 \%$ de probabilidade. De maneira geral, a maior densidade e riqueza total de indivíduos da macrofauna foram encontradas nas áreas PD14 e PD23 na época seca. Porém, maiores índices de equabilidade não foram observados devido à dominância dos grupos Formicidae e Isoptera. As áreas com maiores valores de equabilidade foram a área de referência na época seca e a área PD23 na época chuvosa, com valores de 0,87 e 0,61 , respectivamente. Estes resultados evidenciam a maior diversidade na composição da macrofauna nessas áreas, que reflete a maior estabilidade do ecossistema.

Palavras-chave: Fauna edáfica. Biodiversidade. Bioindicador.

\section{Introduction}

The intensive use of the soil can promote changes in its physical, chemical, and biological properties, and compromise its quality. The soil has a vital role in ecosystems. For this reason, soil quality and degradation are indicators of environmental health and the sustainability of agrosystems (DORAN; PARKIN, 1994; KARLEN et al., 1997; ARAÚJO; MONTEIRO, 2007). The challenge of managing agricultural systems is maintaining productivity while protecting natural resources, soil, water, and biodiversity. The no-tillage system (NTS) follows this premise by promoting greater physical protection of the soil because of the permanent vegetation cover, which continually adds organic matter to the soil, promoting the development of a higher number of both beneficial and pest species (BROWN et al., 2002; SANTOS et al., 2008; SILVA et al., 2013), improving nutrient cycling and the management of pests and diseases (MACHADO et al., 2015).

The chemical and physical characteristics of the soil were better characterized in agricultural management systems, including the NTS (DANTAS et al., 2012). Nonetheless, knowing the composition of the soil faunal community is fundamental to evaluate soil management practices in conservation production systems. The soil macrofauna is an integral and diversified part of the ecosystem biodiversity. The soil macrofauna, including earthworms, insects, and arachnids, has a body diameter ranging from 2 to $20 \mathrm{~mm}$. These organisms play an essential role in the fragmentation of organic matter, soil aeration, predation, nutrient cycling, and regulation of the populations of other invertebrates (MOREIRA et al., 2010; VASCONCELLOS et al., 2013).

The composition, abundance, density, biomass, richness, and diversity of the edaphic macrofauna community is usually changed in areas impacted by activities such as agriculture, pasture, and forest monoculture compared with native forest fragments (COPATTI; DAUDT, 2009; CUNHA; ORLANDO, 2011; MARTINS et al., 2011; MARQUES et al., 2014). However, the decrease in the macrofaunal community may adversely affect the functioning of ecosystems (MACHADO et al., 2015).

In this respect, studies that evaluate ecological parameters of the communities of edaphic macrofauna in degraded areas and areas with tilled soils are relevant to evaluate soil quality and the stage of soil degradation, contributing to the use of the macrofauna as a bioindicator of environmental impact. Therefore, the soil macrofaunal community is used as an indicator of soil biodiversity because of its diversity, functions in the soil, and sensitivity to environmental and/or anthropic changes (VELÁSQUEZ et al., 2007; SNYDER; HENDRIX, 2008; GIEBELMANNA et al., 2010; GIÁCOMO et al., 2017).

In this study, it was assumed that as the soil fauna helps transform the plant matter added to 
the soil surface and improve soil aggregation, this fauna is an important indicator of the effects of the agricultural use of the soil in areas managed under no-tillage for different periods. The objective of this study is to evaluate the effects of the period of implantation of the NTS and seasonality on the diversity, richness, and composition of the edaphic macrofauna.

\section{Materials and Methods}

The study was carried out in commercial production systems implemented and developed in private rural properties managed under NTS for different periods. The areas were located in the community of Maracajú dos Gaúchos in the municipality of Guaíra, state of Paraná, Brazil. The climate of the region according to the classification of Köppen is subtropical ( $\mathrm{Cfa}$ ), with minimum and maximum temperatures of $16{ }^{\circ} \mathrm{C}$ and $28{ }^{\circ} \mathrm{C}$, respectively, and an average annual rainfall of 1600 mm (CAVIGLIONE et al., 2000). The soil of the study sites was classified as typical Eutroferric Red Latosol with clayey texture (SANTOS et al., 2013).

The study sites included three areas managed under NTS and a native Atlantic Forest fragment, which is a natural reserve and was used as a reference. The experimental design was completely randomized. The managed areas were ordered in the following sequences according to the time of implementation of the NTS: NTS7 - 7 years (transition phase), NTS14 - 14 years (consolidation phase), and NTS23 - 23 years (maintenance phase), and each period of implantation was considered one treatment.

In the early 1970 s, native forests were deforested and converted to crops using intense tillage for soil preparation and burning of straw (conventional tillage system, CTS). In the 1990s, the first areas under NTS were formed, and this system was consolidated in the region in the early 2000s (personal information). After conversion from CTS to NTS, the study sites were cultivated with soybean (summer) and maize/wheat (winter). In these areas, fertilization was carried out in the last five years in crop successions of soy and maize/wheat in the following proportions: $270 \mathrm{~kg} \mathrm{ha}^{-1}$ of the formula 02-20-18 and inoculation with Bradyrhizobium japonicum (liquid inoculant: $150 \mathrm{~mL}$ for each $50 \mathrm{~kg}$ of seeds) and $270 \mathrm{~kg} \mathrm{ha}^{-1}$ of the formula $10-15-15$, respectively, and limestone every 4 years at a dose of $1.7 \mathrm{Mg} \mathrm{ha}^{-1}$. The exception was NTS14, in which, after the conversion from CTS to NTS in 1998, the soil was not corrected (personal information).

Soil samples were collected in two seasons: dry season (September 2013) after corn harvest, and rainy season (February 2014) after soybean harvest (Figure 1). In both seasons, samples were collected in the neighboring native Atlantic Forest fragment. In each site, three plots of $1000 \mathrm{~m}^{2}$ were delimited, and three points were marked in each plot, totaling nine points per site, each point representing one repetition. The soil macrofauna community was evaluated using the soil monolith method according to the Tropical Soil Biological and Fertility program (ANDERSON; INGRAM, 1993). 
Figure 1. Rainfall in the region of study from April 2013 to March 2014.

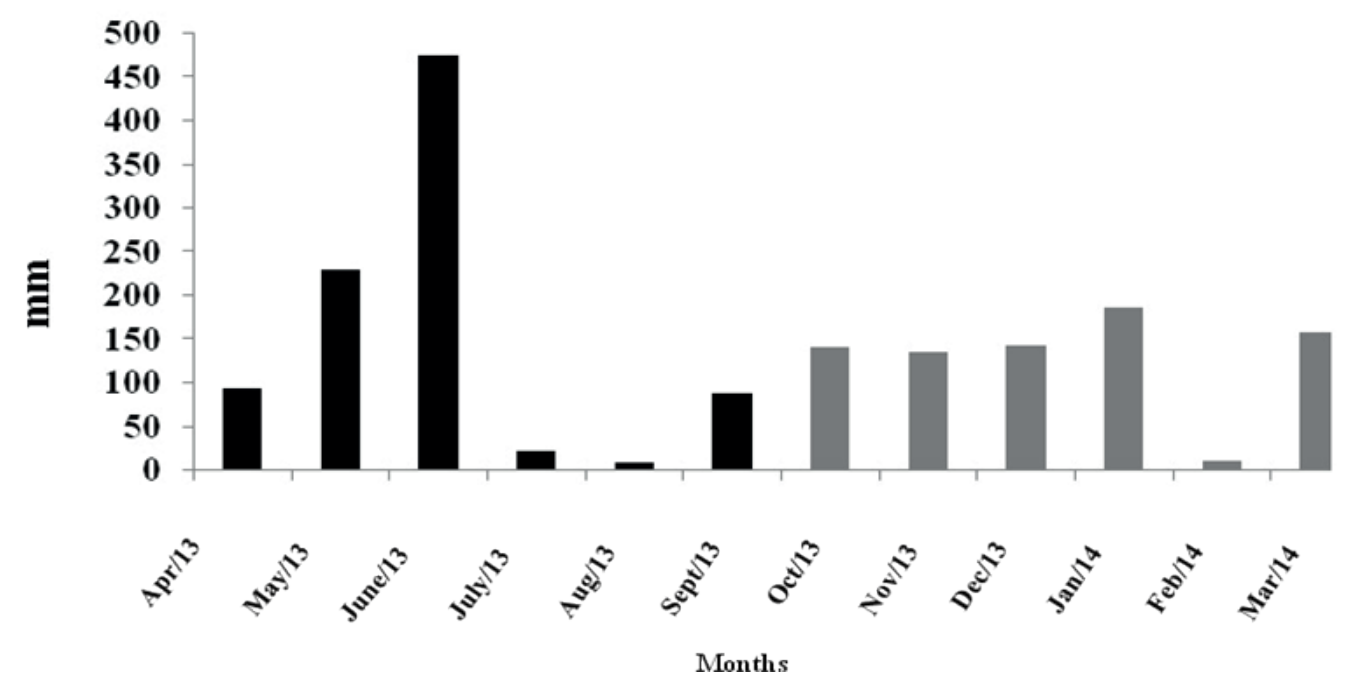

Nine samples (repetitions) were collected in each study site, and the sampled area was delimited by a metal template $(0.25 \times 0.25 \times 0.30 \mathrm{~m})$. The material collected in each site was straw or litter, and soil samples at depths of $0-0.10,0.10-0.20$, and 0.20-0.30 m. In the field, each sample was placed in a tray for manual separation of the macrofauna (visible to the naked eye). The collected specimens were transferred to bottles containing $70 \%$ alcohol for long-term preservation. In the laboratory, the specimens were counted and identified at the level of large taxonomic groups (usually orders and classes) as detailed by Costa et al. (1988), CSIRO (1991), and Dindal (1990). During sampling of the soil macrofauna using monoliths (volume of 0.25 $\times 0.25 \times 0.30 \mathrm{~m}$ ), faunal specimens were removed from the soil and counted by area. Species density was expressed as the number of individuals per $\mathrm{m}^{2}$, and the mean number of sampled individuals was multiplied by 16 , which was the conversion factor between the sampled area $\left(1 / 16 \mathrm{~m}^{2}\right)$ and the square meter.

The soil water content was determined after drying the samples in an oven at $105^{\circ} \mathrm{C}$ until they reached constant weight according to the equation $\mathrm{Ug}(\%)=((\mathrm{WM}-\mathrm{DM}) / \mathrm{DM}) \times 100$, where $\mathrm{WM}$ is the soil wet matter, and DM is the soil dry matter.
The diversity indexes used in this study were total richness, mean richness, and Pielou's evenness. Total richness is the number of taxonomic groups in each area, and mean richness is the average number of taxonomic groups per sample. The following equations were used:

Shannon index $(\mathrm{H})=-\sum$ pi. $\log$ pi, where pi $=$ $\mathrm{ni} / \mathrm{N}$, ni is the density of each group, $\mathrm{N}$ is the sum of the number of individuals per square meter.

Pielou's evenness index $=\mathrm{H}$. $\log \mathrm{S}^{-1}$, where $\mathrm{S}$ is the total richness.

The variables considered in the statistical analysis were species density (total number of individuals in each area) and mean richness. The results were analyzed for normality and homogeneity using the Lilliefors and Cochran test and Bartlett's test, respectively, and Systems for Statistical Analysis (SAEG) software version 8.1 from the Arthur Bernardes Foundation of the Federal University of Viçosa (RIBEIRO JUNIOR, 2001). Species density was calculated by transforming the data to $\log (x+1)$. Considering that the residuals from each treatment presented a normal distribution and the variances were homogeneous, the parametric statistical analysis method was used in a completely randomized design with factorial arrangement [two 
seasons (dry and rainy), three treatments (period of NTS implantation), and nine replicates]. The results were compared by Tukey's test at a level of significance of 5\% using software SISVAR version 4.6 from the Federal University of Lavras (FERREIRA, 2003).

To correlate edaphic macrofauna data with the study sites, multivariate principal component analysis (PCA) was conducted using the statistical package CANOCO (TER BRAAK; SMILAUER, 2002) to assess the degree of influence of the variables (period of implantation of the NTS and seasonality) on data variability.

\section{Results and Discussion}

A total of 3,121 individuals were collected in the dry season. Of the total, $16 \%$ were collected in the NTS $7,48 \%$ in the NTS14, 32\% in the NTS23, and $4 \%$ in the reference area. In the rainy season, of the 1447 collected individuals, $4 \%$ were found in the NTS7, 9\% in the NTS14, 22\% in the NTS23, and $65 \%$ in the reference area. The pattern observed in the native Atlantic Forest fragment indicated that seasonality was an important factor in species density, with the presence of 123 individuals per $\mathrm{m}^{2}$ in the dry season and 937 individuals per $\mathrm{m}^{2}$ in the rainy season (Tables 1 and 2).

Table 1. Total density of the edaphic macrofauna and ecological indexes in the different management systems in the two evaluated periods (dry and rainy).

\begin{tabular}{ccccc}
\hline Areas & Ind. - $^{-2}$ & $\begin{array}{c}\text { Dry season } \\
\text { Average richness }\end{array}$ & Total richness & Pielou's index \\
\hline NTS7 & $512 \pm 329$ & 4.5 & 16 & 0.67 \\
NTS14 & $1480 \pm 803$ & 5 & 17 & 0.33 \\
NTS23 & $1006 \pm 504$ & 4.1 & 13 & 0.52 \\
Atlantic Forest & $123 \pm 30$ & 3 & 12 & 0.87 \\
Total & 3121 & & & \\
\hline & & Rainy season & Total richness & Pielou's index \\
Management systems & Ind.m - $^{2}$ & Average richness & 6 & 0.73 \\
NTS7 & $68 \pm 14$ & 2.5 & 7 & 0.60 \\
NTS14 & $124 \pm 79$ & 1.3 & 8 & 0.61 \\
NTS23 & $318 \pm 215$ & 3.9 & 11 & 0.47 \\
Atlantic Forest & $937 \pm 336$ & 6.1 & & \\
Total & 1447 & & & \\
\hline
\end{tabular}

Values followed by equal capital letters in the same column and the same lowercase letters on the same line do not differ significantly by the Tukey test $(\mathrm{p}<0.05)$.

NTS7 - area under no-tillage with 7 years; NTS14 - - area under no-tillage with 14 years; NTS23 - - area under no-tillage with 23 years. 
Table 2. Density, expressed in ind. $\mathrm{m}^{-2}$ of each taxonomic group under different times of no-tillage and reference area (Atlantic Forest), collected during the dry season.

\begin{tabular}{ccccccccc}
\hline \multicolumn{7}{c}{ Dry season (corn straw) } \\
\hline Groups & NTS7 & $\begin{array}{c}\text { Relat Dens } \\
(\%)\end{array}$ & NTS14 & $\begin{array}{c}\text { Relat Dens } \\
\text { (\%) }\end{array}$ & NTS23 & $\begin{array}{c}\text { Relat Dens } \\
(\%)\end{array}$ & $\begin{array}{c}\text { Atlantic } \\
\text { Forest }\end{array}$ & $\begin{array}{c}\text { Relat Dens } \\
(\%)\end{array}$ \\
\hline Araneae & 9 & 1.76 & 11 & 0.74 & 12 & 1.19 & 4 & 3.25 \\
Blattodea & 0 & 0.00 & 0 & 0.00 & 0 & 0.00 & 2 & 1.63 \\
Chilopoda & 2 & 0.39 & 5 & 0.34 & 12 & 1.19 & 14 & 11.38 \\
Coleoptera & 21 & 4.10 & 34 & 2.30 & 12 & 1.19 & 11 & 8.94 \\
Diplopoda & 9 & 1.76 & 12 & 0.81 & 12 & 1.19 & 9 & 7.32 \\
Diptera & 2 & 0.39 & 2 & 0.14 & 0 & 0.00 & 0 & 0.00 \\
Formicidae & 183 & 35.74 & 139 & 9.39 & 649 & 64.51 & 20 & 16.26 \\
Gastropoda & 11 & 2.15 & 5 & 0.34 & 2 & 0.20 & 2 & 1.63 \\
Heteroptera & 0 & 0.00 & 4 & 0.27 & 18 & 1.79 & 0 & 0.00 \\
Hymenoptera & 2 & 0.39 & 2 & 0.14 & 132 & 13.12 & 0 & 0.00 \\
Isopoda & 0 & 0.00 & 5 & 0.34 & 32 & 3.18 & 0 & 0.00 \\
Isoptera & 0 & 0.00 & 1172 & 79.14 & 0 & 0.00 & 20 & 16.26 \\
Larva Coleoptera & 30 & 5.86 & 28 & 1.89 & 0 & 0.00 & 18 & 14.63 \\
Larva Diptera & 2 & 0.39 & 2 & 0.14 & 0 & 0.00 & 0 & 0.00 \\
Larva Lepidoptera & 4 & 0.78 & 0 & 0.00 & 0 & 0.00 & 0 & 0.00 \\
Larva Formicidae & 132 & 25.78 & 30 & 2.03 & 71 & 7.06 & 0 & 0.00 \\
Lepidoptera & 0 & 0.00 & 11 & 0.74 & 0 & 0.00 & 0 & 0.00 \\
Oligochaeta & 75 & 14.65 & 14 & 0.95 & 44 & 4.37 & 21 & 17.07 \\
Psocoptera & 5 & 0.98 & 0 & 0.00 & 0 & 0.00 & 0 & 0.00 \\
Pseudoscorpionida & 0 & 0.00 & 0 & 0.00 & 2 & 0.20 & 0 & 0.00 \\
Pupa Coleoptera & 0 & 0.00 & 0 & 0.00 & 0 & 0.00 & 2 & 1.63 \\
Sternorryncha & 14 & 2.73 & 0 & 0.00 & 0 & 0.00 & 0 & 0.00 \\
Symphyla & 12 & 2.34 & 5 & 0.34 & 7 & 0.70 & 2 & 1.63 \\
\hline Total & $\mathbf{5 1 2}$ & 100 & $\mathbf{1 4 8 1}$ & 100 & $\mathbf{1 0 0 6}$ & 100 & $\mathbf{1 2 3}$ & 100 \\
\hline $\mathbf{1 6 \% )}$ & & $\mathbf{4 8 \% )}$ & & $\mathbf{3 2 \% )}$ & & $\mathbf{( 4 \% )}$ & \\
\hline
\end{tabular}

NTS7 - area under no-tillage with 7 years; NTS14 - area under no-tillage with 14 years; NTS23 - area under no-tillage with 23 years; Relat Dens - relative density.

The effect of seasonality on the soil macrofauna in forest areas has been evaluated in several studies (MUSSURY et al., 2008; MENEZES et al., 2010; CALVI et al., 2010; CUNHA NETO et al., 2012; MACHADO et al., 2015; BIANCHI et al., 2017). These studies reported that rainfall affected the edaphic macrofauna, as observed in the present study in the rainy season (summer). Although there were only a few millimeters of rain in February of 2014, which affected water soil content at the time of sample collection, rainfall was evenly distributed in the other months (Figure 1).

The 3,122 individuals collected in the dry season belonged to 23 taxonomic groups, including 16 groups in the NTS7, 17 in the NTS14, 13 in the NTS23, and 12 in the reference area (Tables 1 and 2). In the rainy season, the 1447 collected individuals belonged to 13 taxonomic groups, including six groups in the NTS7 area, seven in the NTS14, eight in the NTS23, and 11 in the reference area (Tables 1 and 3$)$. 
Table 3. Density, expressed in ind. $\mathrm{m}^{-2}$ of each taxonomic group under different times of no-tillage and reference area (Atlantic Forest), collected during the rainy season.

\begin{tabular}{ccccccccc}
\hline \multicolumn{10}{c}{ Rainy season (soy straw) } \\
\hline Groups & NTS7 & $\begin{array}{c}\text { Relat Dens } \\
(\%)\end{array}$ & NTS14 & $\begin{array}{c}\text { Relat Dens } \\
(\%)\end{array}$ & NTS23 & $\begin{array}{c}\text { Relat Dens } \\
(\%)\end{array}$ & $\begin{array}{c}\text { Atlantic } \\
\text { Forest }\end{array}$ & $\begin{array}{c}\text { Relat Dens } \\
(\%)\end{array}$ \\
\hline Acari & 0 & 0.00 & 0 & 0.00 & 0 & 0.00 & 4 & 0.43 \\
Araneae & 0 & 0.00 & 5 & 4.03 & 0 & 0.00 & 18 & 1.92 \\
Chilopoda & 2 & 2.94 & 2 & 1.61 & 16 & 5.03 & 21 & 2.24 \\
Coleoptera & 7 & 10.29 & 2 & 1.61 & 11 & 3.46 & 25 & 2.67 \\
Diplopoda & 0 & 0.00 & 20 & 16.13 & 18 & 5.66 & 16 & 1.71 \\
Formicidae & 0 & 0.00 & 87 & 70.16 & 203 & 63.84 & 171 & 18.25 \\
Heteroptera & 2 & 2.94 & 0 & 0.00 & 0 & 0.00 & 0 & 0.00 \\
Hymenoptera & 0 & 0.00 & 0 & 0.00 & 2 & 0.63 & 0 & 0.00 \\
Isopoda & 0 & 0.00 & 0 & 0.00 & 0 & 0.00 & 4 & 0.43 \\
Isoptera & 0 & 0.00 & 0 & 0.00 & 0 & 0.00 & 629 & 67.13 \\
Larva Coleoptera & 16 & 23.53 & 0 & 0.00 & 32 & 10.06 & 34 & 3.63 \\
Oligochaeta & 41 & 60.29 & 9 & 7.26 & 32 & 10.06 & 14 & 1.49 \\
Symphyla & 0 & 0.00 & 0 & 0.00 & 5 & 1.57 & 2 & 0.21 \\
\hline Total & $\mathbf{6 8}$ & 100 & $\mathbf{1 2 4}$ & 100 & $\mathbf{3 1 8}$ & 100 & $\mathbf{9 3 7}(\mathbf{6 5 \% )}$ & 100 \\
\hline
\end{tabular}

NTS7 - area under no-tillage with 7 years; NTS14 - area under no-tillage with 14 years; NTS23 - area under no-tillage with 23 years; Relat Dens - relative density.

There was no significant increase in total richness between the two seasons, with the identification of 12 groups in the dry season and 11 groups in the rainy season. Pielou's evenness index was higher in the dry season, indicating that there was no dominance between the taxonomic groups in this period. In contrast, Pielou's evenness was lower in the rainy season, and this result was attributed to the larger number of individuals from the Isoptera group. The rainfall regime was characterized by frequent rains in the rainy season, except in February 2014, when rainfall was comparatively lower (Figure 1). This regime may have affected the results, especially the distribution of edaphic macrofauna in the managed areas.

In managed areas, in addition to seasonality, the type of vegetation cover was different between the two seasons. In the dry season, the vegetation cover was composed of corn straw and the previous crop was soybean whereas, in the rainy season, the cover was composed of soybean straw, and the previous crop was maize. The previous crop affected the soil straw composition. The comparison of the managed areas revealed that the total density of individuals (68 per $\mathrm{m}^{2}$ ) and total richness (six groups) were lower in the rainy season when the vegetation cover was soybean straw. In the dry season, when the vegetation cover was maize straw, the total density and total richness were increased, corresponding to 1480 per $\mathrm{m}^{2}$ and 17 groups, respectively. The groups with higher density were Formicidae in the NTS7 and NTS23 and Isoptera in the NTS14 in the dry season. In the rainy season, the dominant groups were Formicidae in the NTS23 and Isoptera in the reference area.

Pielou's evenness was similar between the managed areas and reference area. However, in the dry season, species density was relatively higher, and Pielou's evenness was lower in all evaluated areas, indicating the dominance of some taxonomic groups in this period. The NTS14 presented the highest species density (1480 per $\mathrm{m}^{2}$ ) and highest 
total richness (17 groups) in the dry season. In contrast, in this same site, Pielou's evenness was relatively lower, indicating the dominance of some taxonomic groups in the NTS14 in this period. The dominance of the Isoptera group relative to the other groups is shown in Table 2.

In the NTS7 and NTS23, Formicidae presented the highest density, corresponding to 183 and 649 individuals per $\mathrm{m}^{2}$, respectively (Table 2 ). The high density of ants and termites may be related to their social habits and the constant addition of organic matter to the soil, with a tendency to collect a large number of individuals from this taxonomic group (MENEZES et al., 2009). Ants are conspicuous in most terrestrial ecosystems because of their abundance and species richness (LONGINO, 2002), and the high density of this group has been reported in several studies (MENEZES, 2008; MARTINS et al., 2009; KLENK, 2010; MACHADO et al., 2015; BIANCHI et al., 2017). In addition to ants, termites feed on cellulosic material, accelerating the decomposition and cycling of nutrients present in dead plant material (OUÉDRAOGO et al., 2004; MELO et al., 2009), and build galleries, nests, and tunnels in the soil in search for food resources, consequently improving soil aggregation, porosity, aeration, and infiltration (MELO et al., 2009; KORASAKI et al., 2017).

The group Oligochaeta was present in all areas in both seasons (Table 2), but its density was higher in the NTS7 (75 individuals per $\mathrm{m}^{2}$ ), where this group was better distributed relative to the other managed areas (Table 2). The density of some faunal groups such as Oligochaeta is strongly associated with soils with low anthropogenic activity and high levels of organic matter. Cultures such as maize have a relatively high root density, resulting in high levels of organic matter (LOSS et al., 2011).
Total richness was usually higher in all evaluated areas in the dry season, when the soil was covered with corn straw, compared to the rainy season, when the soil was covered with soy straw. Moreover, some groups were more dominant in this season, including Diptera, Gastropoda, Diptera (larvae), Lepidoptera (larvae), Formicidae (larvae), Lepidoptera, Psocoptera, Pseudoscorpionida, Coleoptera (pupae), and Sternorryncha (Tables 2 and 3). This result can be explained by the larger amount of straw from maize crops and the higher $\mathrm{C} / \mathrm{N}$ ratio. These two factors delay straw decomposition, guaranteeing a larger supply of food resources on the soil surface, with differences in composition and microhabitats, consequently increasing species density and total richness.

The results indicated that there were no significant differences in species density in the dry season between the study sites. In the rainy season, at a depth of $0.20-0.30 \mathrm{~m}$, there was a significant difference in species density between the managed areas and the reference area, and this variable was higher $\left(387\right.$ per $\left.\mathrm{m}^{2}\right)$ in the native forest fragment. This result is related to the high abundance of individuals from the groups Formicidae and Isoptera, accounting to $29.8 \%$ and $65.6 \%$ of the total at this soil depth, leading to an increase species density.

Species density was lower in the rainy season at all depths. At a depth of $0-0.10 \mathrm{~m}$, the density was lower in the NTS7 than in the other areas. This variable was lower in the NTS23 at a depth of $0.10-0.20 \mathrm{~m}$ and lower in the NTS7 and NTS14 at a depth of $0.20-0.30 \mathrm{~m}$. In both cases, this result was affected by the higher density of groups Formicidae and Isoptera (Table 4). 
Table 4. Density of the edaphic macrofauna (Ind. $\mathrm{m}^{-2}$ ) at depths of 0-0.10, 0.10-0.20 and 0.20-0.30 $\mathrm{m}$ in the different management systems and seasons (dry and rainy).

\begin{tabular}{|c|c|c|c|c|}
\hline \multirow[t]{2}{*}{ Areas } & \multicolumn{2}{|c|}{ Ind.m-2 } & \multicolumn{2}{|c|}{ Average richness } \\
\hline & Dry & Rainy & Dry & Rainy \\
\hline \multicolumn{5}{|c|}{$0-0,10 \mathrm{~m}$} \\
\hline NTS7 & $76 \pm 24 \mathrm{Aa}$ & $36 \pm 12 \mathrm{Aa}$ & $1.44 \mathrm{Aa}$ & $1.55 \mathrm{ABa}$ \\
\hline NTS14 & $295 \pm 155 \mathrm{Aa}$ & $25 \pm 11 \mathrm{Ab}$ & $3.88 \mathrm{Aa}$ & $0.88 \mathrm{Bb}$ \\
\hline NTS23 & $188 \pm 104 \mathrm{Aa}$ & $267 \pm 219 \mathrm{Aa}$ & $2.33 \mathrm{Aa}$ & $2.55 \mathrm{ABa}$ \\
\hline \multirow[t]{2}{*}{ Atlantic Forest } & $53 \pm 21 \mathrm{Aa}$ & $284 \pm 156 \mathrm{Aa}$ & $1.66 \mathrm{Ab}$ & $3.88 \mathrm{Aa}$ \\
\hline & \multicolumn{2}{|c|}{$\mathrm{CV}(\%)=61.43$} & \multicolumn{2}{|c|}{$\mathrm{CV}(\%)=89.39$} \\
\hline \multicolumn{5}{|c|}{$0,10-0,20 \mathrm{~m}$} \\
\hline NTS7 & $59 \pm 22 \mathrm{Aa}$ & $18 \pm 5 \mathrm{Aa}$ & $1.66 \mathrm{Aa}$ & $0.88 \mathrm{Aa}$ \\
\hline NTS14 & $75 \pm 41 \mathrm{Aa}$ & $98 \pm 82 \mathrm{Aa}$ & $1.33 \mathrm{Aa}$ & $0.88 \mathrm{Aa}$ \\
\hline NTS23 & $622 \pm 522 \mathrm{Aa}$ & $28 \pm 13 \mathrm{Ab}$ & $2.66 \mathrm{Aa}$ & $1.11 \mathrm{Ab}$ \\
\hline \multirow[t]{2}{*}{ Atlantic Forest } & $37 \pm 14 \mathrm{Aa}$ & $264 \pm 202 \mathrm{Aa}$ & $1.22 \mathrm{Ab}$ & $2.55 \mathrm{Aa}$ \\
\hline & \multicolumn{2}{|c|}{$\mathrm{CV}(\%)=67,94$} & \multicolumn{2}{|c|}{$\mathrm{CV}(\%)=88.98$} \\
\hline \multicolumn{5}{|c|}{$0,20-0,30 \mathrm{~m}$} \\
\hline NTS7 & $384 \pm 310 \mathrm{Aa}$ & $23 \pm 9 \mathrm{Bb}$ & $2.77 \mathrm{Aa}$ & $1.00 \mathrm{Ab}$ \\
\hline NTS14 & $1111 \pm 724 \mathrm{Aa}$ & $11 \pm 6 \mathrm{Bb}$ & $1.44 \mathrm{Aa}$ & $0.44 \mathrm{Aa}$ \\
\hline NTS23 & $196 \pm 137 \mathrm{Aa}$ & $23 \pm 8 \mathrm{Ba}$ & $1.77 \mathrm{Aa}$ & $1.33 \mathrm{Aa}$ \\
\hline \multirow[t]{2}{*}{ Atlantic Forest } & $32 \pm 10 \mathrm{Ab}$ & $387 \pm 135 \mathrm{Aa}$ & $1.33 \mathrm{Aa}$ & $2.22 \mathrm{Aa}$ \\
\hline & \multicolumn{2}{|c|}{$\mathrm{CV}(\%)=72,20$} & \multicolumn{2}{|c|}{$\mathrm{CV}(\%)=100,98$} \\
\hline
\end{tabular}

Values followed by equal capital letters in the same column and the same lowercase letters on the same line do not differ significantly by the Tukey test $(\mathrm{p}<0.05)$

NTS7 - area under no-tillage with 7 years; NTS14 - area under no-tillage with 14 years; NTS23 - area under no-tillage with 23 years.

There were significant differences in mean richness at different depths in the rainy season. This variable was relatively lower in the NTS14 at a depth of 0-0.10 m, lower in the NTS23 at a depth of 0.10-0.20 m, and lower in the NTS7 at a depth of 0.20-0.30 m (Table 4).

PCA indicated that $46 \%$ of data variability was explained in PC1 and $20.2 \%$ in PC2, totaling $66.20 \%$ of the variability present in the original data (Figure 2). The period of implementation of the NTS strongly affected the macrofauna community, and the longer was the time under NTS, the higher was the diversity of the soil macrofauna. The areas with a shorter time of implementation of the
NTS tended to contain phytophagous organisms, including Sternorryncha, and the no-tillage system and addition of organic matter to the soil surface increased the participation of saprophagous organisms and predators, including Oligochaeta, Isopoda, and Araneae (ALVES et al., 2006; VEZZANI; MIELNICZUK, 2011). The reference area presented a distinct pattern, explained by the heterogeneous environment and higher biodiversity (more stable microclimate, including temperature and relative humidity) compared to the managed areas, and the group Isoptera predominated in this system. 
Figure 2. Relationship between macrofauna variables and factors (time of adoption of no-tillage and seasonality) with the main components 1 e 2 (CP 1 e CP 2).

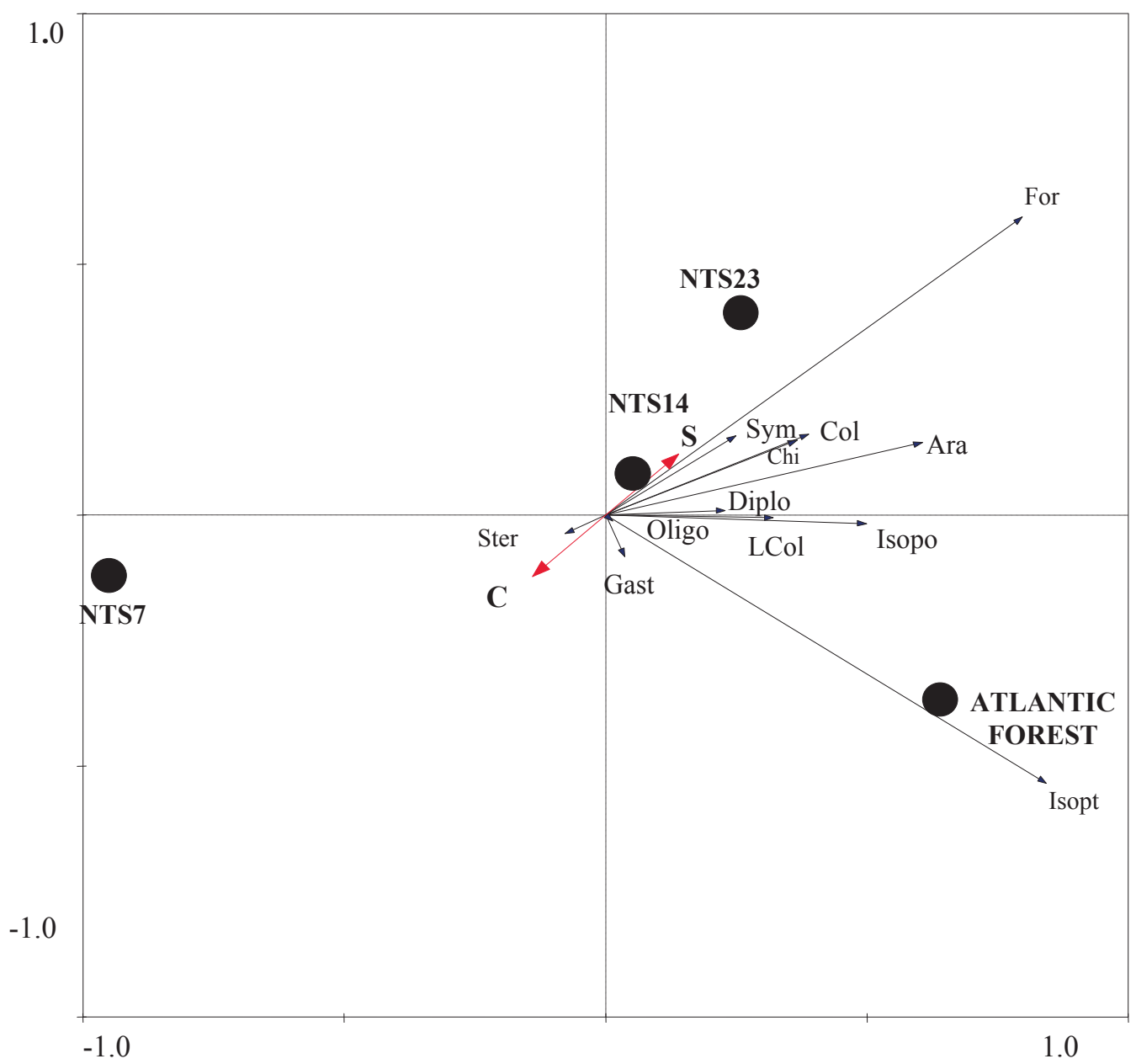

NTS7 - area under no-tillage with 7 years; NTS14 - area under no-tillage with 14 years; NTS23 - area under no-tillage with 23 years, S - dry season, C - rainy season. Araneae (Ara), Chilopoda (Chi), Coleoptera (Col), Diplopoda (Diplo), Formicidae (For), Gastropoda (Gast) Isopoda (Iso), Isoptera (Isopo), Isoptera (Isopt) Larva de Coleoptera (LCol), Oligochaeta (Oligo), Sternorryncha (Ster), Symphyla (Sym).

\section{Conclusions}

The period of implantation of no-tillage systems had a stronger effect on the diversity of the soil macrofauna than seasonality.

The species density and total richness of the macrofauna were higher in the areas managed under no-tillage, including the NTS14 and NTS23 in the dry season. However, Pielou's evenness index was not higher in these areas because of the dominance of the groups Formicidae and Isoptera.
Pielou's evenness was comparatively higher in the native Atlantic Forest fragment in the dry season and in the NTS23 in the rainy season, with values of 0.87 and 0.61 , respectively.

\section{References}

ALVES, M. V.; BARETTA, D.; CARDOSO, E. J. B. N. Fauna edáfica em diferentes sistemas de cultivo no Estado de São Paulo. Revista de Ciências Agroveterinárias, Lages, v. 5, n. 1, p. 33-43, 2006. 
ANDERSON, J. M.; INGRAM, J. S. I. Tropical soil biological and fertility: a handbook of methods. Oxford: Wallingford: CAB International, 1993. $221 \mathrm{p}$.

ARAÚJO, A. S. F.; MONTEIRO, R. T. R. Indicadores biológicos de qualidade do solo. Bioscience Journal, Uberlândia v. 23, n. 3, p. 66-75, 2007.

BIANCHI, M. O.; SCORIZA, R. N.; RESENDE, A. S.; CAMPELLO, E. F. C.; CORREIA, M. E. F.; SILVA, E. M. R. Macrofauna edáfica como indicadora em revegetação com leguminosas arbóreas. Revista Floresta e Ambiente, Seropédica, v. 24, n. 1, p. 1-8, 2017.

BROWN, G. G.; PASINI, A.; BENITO, N. P.; AQUINO A. M.; CORREIA, M. E. F. Diversity and functional role of soil macrofauna communities in Brazilian notillage agroecosystems: a preliminary analysis. In: INTERNATIONAL SYMPOSIUM ON MANAGING BIODIVERSITY INAGRICULTURALECOSYSTEMS, 2002, Montreal. Proceedings... Montreal: UNU/CBD, 2002. CD-ROM.

CALVI, G. P.; PEREIRA, M. G.; ESPINDULA JUNIOR, A.; MACHADO, D. L. Composição da fauna edáfica em duas áreas de floresta em Santa Maria de Jetibá, ES, Brasil. Acta Agronómica, Palmira: Universidad Nacional de Colombia, v. 59, n. 1, p. 37-45, 2010.

CAVIGLIONE, J. H.; KIIHL, L. R. B.; CARAMORI, P. H.; OlIVEIRA, D. Cartas climáticas do Paraná. Londrina: IAPAR, 2000. CD-ROM.

COMMONWEALTH SCIENTIFIC AND INDUSTRIAL RESEARCH ORGANISATION - CSIRO. The insects of Australia: a textbook for students and research workers. $2^{\text {th }}$ ed. New York: Cornell University Press, 1991. 1136 p.

COPATTI, C. E.; DAUDT, C. R. Diversidade de artrópodes na serapilheira em fragmentos de mata nativa e Pinus elliottii. Ciência e Natura, Santa Maria, v. 31, n. 1, p. 95-113, 2009.

COSTA, C.; VANIN, S. A.; CASARI-CHEN, S. A. Larvas de coleóptera do Brasil. São Paulo: Museu de Zoologia, 1988. $282 \mathrm{p}$.

CUNHA NETO, F. V.; CORREIA, M. E. F.; PEREIRA, G. H. A.; PEREIRA, M. G.; LELES, P. S. S. Soil fauna as an indicator of soil quality in forest stands, pasture and secondary forest. Revista Brasileira de Ciência do Solo, Viçosa, MG, v. 36, n. 5, p. 1407-1417, 2012.

CUNHA, H. F.; ORLANDO, T. Y. S. Functional composition of termite species in areas of abandoned pasture and in secondary succession of the Parque Estadual Altamiro de Moura Pacheco, Goiás, Brazil. Bioscience Journal, Uberlândia, v. 27, n. 6, p. 986- 992, 2011.
DANTAS, J. D. A. N.; OLIVEIRA, T. S.; MENDONÇA, E. S.; ASSIS, C. P. Qualidade de solo sob diferentes usos e manejos no perímetro irrigado Jaguaribe/Apodi, CE. Revista Brasileira de Engenharia Agrícola e Ambiental, Campina Grande, v. 16, n. 1, p. 18-26, 2012.

DINDAL, D. Soil biology guide. New York: John Wiley \& Sons, 1990. 1348 p.

DORAN, J. W.; PARKIN, T. B. Defining and assessing soil quality. In: DORAN, J. W.; COLEMAN, D. C.; BEZDICEK, D. F.; STEWARD, B. A. (Ed.). Defining soil quality for a sustainable environment. Madison: SSSA. American Society of Agronomy, 1994. p. 3-21. (Special Public, 35).

FERREIRA, D. F. SISVAR 4.6: sistema de análises estatísticas. Lavras: UFLA, 2003. 32 p.

GIÁCOMO, R. G.; SOUZA, R. C.; ALVES, M. C.; PEREIRA, M. G.; ARRUDA, O. G.; GONZÁLEZ, A. P. Soil fauna: bioindicator of soil recovery in Brazilian savannah. Revista Brasileira de Ciências Agrárias, Recife, v. 12, n. 2, p. 236-243, 2017.

GIEBELMANNA， U. C.; MARTINS, K. G.; BRÄNDLEA, M.; SHÄDLER, M.; MARQUES, R.; BRANDL, R. Diversity and ecosystem functioning: litter decomposition dynamics in the Atlantic Rainforest. Applied Soil Ecology, Amsterdam, v. 46, n. 2, p. 283-290, 2010.

KARLEN, D. L.; MAUSBACH, M. J.; DORAN, J. W.; CLINE, R. G.; HARRIS, R. F.; SCHUMAN, G. E. Soil quality: a concept, definition, and framework for evaluation. Soil Science Society American Journal, Madison. v. 61, n. 1, p. 4-10, 1997.

KLENK, L. A. Macrofauna invertebrada edáfica em pastagem com pastoreio rotativo sob diferentes preparos orgânicos em condições subtropicais no sul do Brasil. 2010. Dissertação (Mestrado em Ciência do Solo) Universidade Federal do Paraná, Curitiba.

KORASAKI, V.; FERREIRA, R. S.; OLIVEIRA, E.; FRANÇA, F.; AUDINO, L. D. Macrofauna. Lavras: Editora UFLA, 2017. 32 p.

LONGINO, J. I.; CODDINGTON, J. A.; COLWELL, R. K. The ant fauna of a tropical rainforest: estimating species richness three different ways. Ecology, California: University of California, v. 83, n. 3, p. 689-702, 2002.

LOSS, A.; PEREIRA, M. G.; GIÁCOMO, S. G.; PERIN, A.; ANJOS, L. H. C. A. Agregação, carbono e nitrogênio em agregados do solo sob plantio direto com integração lavoura-pecuária. Pesquisa Agropecuária Brasileira, Brasília, v. 46, n. 10, p. 1269-1276, 2011. 
MACHADO, D. L.; PEREIRA, M. G.; CORREIA, M. E. F.; DINIZ, A. R.; MENEZES, C. E. G. Fauna edáfica na dinâmica sucessional da Mata Atlântica em floresta estacional semidecidual na Bacia do Rio Paraíba do Sul RJ. Ciência Florestal, Santa Maria, v. 25, n. 1, p. 91-106, 2015.

MARQUES, D. M.; SILVA, A. B. da.; SILVA, L. M. da; MOREIRA, E. A.; PINTO, G. S. Macrofauna edáfica em diferentes coberturas vegetais. Bioscience Journal, Uberlância, v. 30, n. 5, p. 1588-1597, 2014.

MARTINS, E. L.; CORINGA, J. E. S.; WEBER, O. L. S. Carbono orgânico das frações granulométricas e substânicas húmicas de um Latossolo Vermelho Amarelo Distrófico- LVAd sob diferentes agrossistemas. Acta Amazonica, Manaus, v. 39, n. 3, p. 655-660, 2009.

MARTINS, L.; ALMEIDA, F. S.; MAYHÉ-NUNES, A. J.; VARGAS, A. B. Efeito da complexidade estrutural do ambiente sobre as comunidades de formigas (Hymenoptera: Formicidae) no município de Resende, RJ, Brasil. Revista Brasileira de Biociências, Porto Alegre, v. 9, n. 2, p. 174-179, 2011.

MELO, F. V.; BROWN, G. G.; CONSTANTINO, R.; LOUZADA, J. N. C.; LUIZÃO, F. J.; MORAIS, J. W.; ZANETTI, R. Importância da meso e macrofauna do solo na fertilidade e como bioindicadores. Boletim Informativo da Sociedade Brasileira de Ciência do Solo, v. 34, n. 1, p. 39-43, 2009.

MENEZES, C. E. G. Integridade de paisagem, manejo e atributos do solo no Médio Vale do Paraiba do Sul, Pinheiral- RJ. 2008. Tese (Doutorado em Ciência do Solo) - Universidade Federal Rural do Rio de Janeiro, Seropédica.

MENEZES, C. E. G.; BROWN, G. G.; CONSTANTINO, R.; LOUZADA, J. N. C.; LUIZÃO, F. J.; MORAIS, J. W.; ZANETTI, R. de. Macrofauna edáfica em estágios sucessionais de floresta estacional semidecidual e pastagem mista em Pinheiral (RJ). Revista Brasileira de Ciência do Solo, Viçosa, MG, v. 33, n. 6, p. 1647-1656, 2009.

MENEZES, C. E. G.; PEREIRA, M. G.; CORREIA, M. E. F.; ANJOS, L. H. C.; PAULA, R. R.; SOUZA, M. E. Aporte e decomposição da serrapilheira e produção de biomassa radicular em florestas com diferentes estágios sucessionais em Pinheiral, RJ. Ciência Florestal, Santa Maria, v. 20, n. 3, p. 439-452, 2010.

MOREIRA, F. M. S.; HUISING, J.; BIGNELL, D. E. Manual de biologia dos solos tropicais. Amostragem e caracterização da biodiversidade. Lavras: UFLA, 2010. v. $1,368 \mathrm{p}$.

MUSSURY, R. M.; SCALON, S. P. Q.; GOMES, A.
A.; BATISTA, M. R.; SCALON FILHO, H. Flutuação populacional da mesofauna em fragmentos de mata na região de Dourados, MS. Revista Ciência e Agrotecnologia, Lavras, v. 32, n. 2, p. 645-650, 2008.

OUÉDRAOGO, E.; MANDO, A.; BRUSSAARD, L. Soil macrofaunal-mediated organic resource disappearance in semi-arid West Africa. Applied Soil Ecology, Amsterdam, v. 27, n. 3, p. 259-267, 2004.

RIBEIRO JUNIOR, J. I. Análises estatísticas no SAEG. Viçosa, MG: Universidade Federal de Viçosa, 2001. 301 p.

SANTOS, G. G.; SILVEIRA, P. M.; MARCHÃO, R. L.; BECQUER, T.; BALBINO, L. C. Macrofauna edáfica associada a plantas de cobertura em plantio direto em um Latossolo Vermelho do Cerrado. Pesquisa Agropecuária Brasileira, Brasília, v. 43, n. 1, p. 115-122, 2008.

SANTOS, H. G.; JACOMINE, P. K. T.; ANJOS, L. H. C.; OLIVEIRA, V. A.; LUMBRERAS, J. F.; COELHO, M. R.; ALMEIDA, J. A.; CUNHA, T. J. F.; OLIVEIRA, J. B. Sistema brasileiro de classificação de solos. 3. ed. Brasília: EMBRAPA, 2013. 353 p.

SILVA, R. F.; CORASSA, G. M.; BERTOLLO, G. M.; SANTI, A. L.; STEFFEN, R. B. Fauna edáfica influenciada pelo uso de culturas e consórcios de cobertura do solo. Pesquisa Agropecuária Tropical, Goiânia, v. 43, n. 2, p. 130-137, 2013.

SNYDER, B. A.; HENDRIX, P. F. Current and potential roles of soil macroinvertebrates (earthworms, millipedes and isopods) in ecological restoration. Restoration Ecology, Crawley, v. 16, n. 4, p. 629-636, 2008.

TER BRAAK, C. J. F.; SMILAUER, P. Canoco reference manual and Canodraw for Windows User's Guide: software for canonical community ordination (Version 4. 5). Ithaca: Micrófagoscomputer Power, 2002. 500 p.

VASCONCELLOS, R. L. F.; SEGAT, J. C.; BONFIM, J. A.; BARETTA, D.; CARDOSO E. J. B. N. Soil macrofauna as an indicator of soil quality in an(?) undisturbed ripariam forest and recovering sites of different ages. European Journal of Soil Biology, Amsterdã, v. 58, n. 1, p. 105-112, 2013.

VELÁSQUEZ, E.; PELOSI, C.; BRUNET, D.; GRIMALDI, M.; MARTINS, M.; RENDEIRO, A. C.; BARRIOS, E.; LAVELLE, P. This ped is my ped: visual separation and near infrared spectra allow determination of the origins of soil macroaggregates. Pedobiologia, Amsterdã, v. 51, n. 1, p. 75-87, 2007.

VEZZANI, F. M.; MIELNICZUK, J. Agregação e estoque de carbono em argissolo submetido a diferentes práticas de manejo agrícola. Revista Brasileira de Ciência do Solo, Viçosa, MG, v. 35, n. 1, p. 213-223, 2011. 